Pesq. Vet. Bras. 35(10):829-834, outubro 2015 DOI: 10.1590/S0100-736X2015001000002

\title{
Presence of Porphyromonas and Prevotella species in the oral microflora of cattle with periodontitis ${ }^{1}$
}

\author{
Ana Carolina Borsanelli², Elerson Gaetti-Jardim Júnior ${ }^{3}$, Christiane Marie Schweitzer ${ }^{4}$, \\ Jürgen Döbereiner ${ }^{5}$ and Iveraldo S. Dutra ${ }^{6 *}$
}

\begin{abstract}
ABSTRATC.- Borsanelli A.C., Gaetti-Jardim Júnior E., Schweitzer C.M., Döbereiner J. \& Dutra I.S. 2015. Presence of Porphyromonas and Prevotella species in the oral microflora of cattle with periodontitis. Pesquisa Veterinária Brasileira 35(10):829-834. Departamento de Apoio, Produção e Saúde Animal, Faculdade de Medicina Veterinária de Araçatuba, Unesp, Campus de Araçatuba, Rua Clóvis Pestana 793, Jardim Dona Amélia, Araçatuba, SP 16050-680, Brazil. E-mail: isdutra@fmva.unesp.br

Bovine periodontitis is a progressive purulent infectious process associated with the presence of strictly and facultative anaerobic subgingival biofilm and epidemiologically related to soil management in large geographic areas of Brazil. This study aimed to detect species of the genera Porphyromonas and Prevotella, which occurr in periodontal pockets of cattle with lesions deeper than $5 \mathrm{~mm}(\mathrm{n}=26)$ and in gingival sulcus of animals considered periodontally healthy $(n=25)$. Presence of the microorganisms was evaluated by independent-culture medium diagnostic method, using polymerase chain reaction (PCR) with specific primers of Porphyromonas asaccharolytica, $P$. endodontalis, P. gingivalis, $P$. gulae, Prevotella buccae, P. intermedia, P. loescheii, P. melaninogenica, P. nigrescens, $P$. oralis and $P$. tannerae. The species P. endodontalis (80.7\%), P. melaninogenica $(73.1 \%)$ and P. intermedia $(61.5 \%)$ were the most predominant in samples of cattle with periodontitis. Regarding non -injured gingival sulcus of cattle, P. endodontalis (40\%) and P. loeschei (40\%) prevailed. Porphyromonas gingivalis, P. gulae and Prevotella tannerae were not detected in the 51 samples studied. Data evaluation by T test, enabled to verify that ocorrence of Porphyromonas asaccharolytica $(p=0.000003), P$. endodontalis $(p=0.0023)$, Prevotella buccae $(p=0.0017), P$. intermedia $(p=0.0020), P$. melaninogenica $(p=0.00006)$ and $P$. oralis $(p=0.0028)$ is correlated with bovine periodontitis.
\end{abstract}

INDEX TERMS: Porphyromonas spp., Prevotella spp., periodontitis, cattle.

\footnotetext{
${ }^{1}$ Received on May 28, 2015.

Accepted for publication on September 4, 2015

${ }^{2}$ Programa de Pós-Graduação em Medicina Veterinária, Faculdade de Ciências Agrárias e Veterinárias, Universidade Estadual Paulista (Unesp), Via de Acesso Professor Paulo Donato Castellane s/n, Jaboticabal, SP 14884-900, Brazil. E-mail: carol_borsanelli@yahoo.com.br

${ }^{3}$ Departamento de Patologia e Propedêutica Clínica, Faculdade de Odontologia de Araçatuba, Unesp, Rua José Bonifácio 1193, Araçatuba, SP 16015-050, Brazil. E-mail: gaettijardim@gmail.com

${ }^{4}$ Departamento de Matemática, Faculdade de Engenharia de Ilha Solteira, Unesp, Alameda Rio de Janeiro 266, Ilha Solteira, SP 15385-000, Brazil. E-mail: chris@mat.feis.unesp.br

${ }^{5}$ Ex-Pesquisador da Empresa Brasileira de Pesquisa Agropecuária (Embrapa), General Editor of "Pesquisa Veterinária Brasileira", Seropédica, RJ 23890-000, Brazil. E-mail: jurgen.dobereiner@pvb.com.br

${ }^{6}$ Departamento de Apoio, Produção e Saúde Animal, Faculdade de Medicina Veterinária de Araçatuba, Unesp, Campus de Araçatuba, Rua Clóvis Pestana 793, Jardim Dona Amélia, Araçatuba, SP 16050-680. *Corresponding author: isdutra@fmva.unesp.br
}

RESUMO.- [Presença de espécies de Porphyromonas e Prevotella na microbiota oral de bovinos com periodontite.] A periodontite bovina é um processo infeccioso purulento e progressivo associado à presença de biofilme subgengival anaeróbio estrito e facultativo e de incidência em extensas áreas geográficas do Brasil. 0 trabalho teve por objetivo detectar espécies dos gêneros Porphyromonas e Prevotella presentes na bolsa periodontal de bovinos com lesões de profundidade maior que $5 \mathrm{~mm}(\mathrm{n}=26)$ e do sulco gengival de animais com idade de 6 a 24 meses e considerados periodontalmente sadios $(n=25)$. A presença dos microrganismos foi avaliada pelo método independente de cultivo bacteriano, por meio da reação em cadeia da polimerase (PCR) com iniciadores específicos para Porphyromonas asaccharolytica, $P$. endodontalis, $P$. gingivalis, $P$. gulae, Prevotella buccae, P. intermedia, P. loescheii, P. melalinogenica, P. nigrescens, P. oralis e P. tannerae. P. endodontalis 
$(80,7 \%)$, P. melalinogenica $(73,1 \%)$ e P. intermedia $(61,5 \%)$ foram os mais prevalentes nas amostras de bovinos com periodontite. Já no sulco gengival de bovinos sem lesões prevaleceram P. endodontalis (40\%) e P. loeschei (40\%). Porphyromonas gingivalis, P. gulae e Prevotella tannerae não foram detectados nas 51 amostras pesquisadas. A partir da avaliação dos dados pelo teste T, verificou-se que a ocorrência de Porphyromonas asaccharolytica ( $p=0.000003), P$. endodontalis ( $p=0.0023)$, Prevotella buccae $(p=0.0017), P$. intermedia $(p=0.0020), P$. melalinogenica $(p=0.00006)$ e $P$. oralis ( $p=0.0028$ ) está associada à periodontite bovina.

TERMOS DE INDEXAÇÃO: Porphyromonas spp., Prevotella spp., periodontite bovina.

\section{INTRODUCTION}

"Cara inchada" in cattle is a progressive, purulent periodontitis, with macroscopic and histological changes, which usually initiate in the papilla between the second and third deciduous maxillary premolars, with periodontal pocket formation. Next, food particles are accumulated, fact that worsen the process, determining injury increase, extension and depth; resulting in a chronic periostitis ossificans. With alveolar purulent process development, the tooth roots become exposed with loosening and loss of teeth (Döbereiner et al. 1974).

The occurrence of the periodontitis is associated with presence and prevalence of anaerobic Gram-negative non-sporulating bacteria forming black-pigmented colonies in culture medium with hemin and $\mathrm{K}$ vitamin (Blobel et al. 1984, Botteon et al. 1993, Dutra et al. 1986, 2000). The disease has great economic and sanitary impact on Brazilian livestock and shows peculiar epidemiological characteristics. Initially associated with pasture formation in extensive areas of south-eastern, central-western and northern regions of the country (Döbereiner et al. 2000), the disease reoccurs with great prevalence of its apparent clinical manifestation in herds after pasture reformation or when cattle in dentition stage were fed with forage cultivated in endemic areas (Dutra et al. 1993, Döbereiner et al. 2000).

Anaerobic bacteria are predominant in the oral microflora of humans and several animal species, highlighting the anaerobic Gram-negative producers of black pigment, which belong to the Porphyromonas and Prevotella gene$\mathrm{ra}$, and were identified in cases of chronic periodontitis, biofilm associated gingivitis and osteomyelitis in humans (Ashimoto et al. 1996, Socransky et al. 1998, Mayanagi et al. 2004, Gaetti-Jardim Jr et al. 2010). In pet animals, these microorganisms were also identified in the oral microflora of cats with or without periodontal disease (Mallonee et al. 1988, Love et al. 1989, Love et al. 1990) as well as in periodontal pockets of dogs (Hardham et al. 2005, Nishiyama et al. 2007, Riggio et al. 2011, Senhorinho et al. 2011). The two genera are likely to predominate in lesions of bovine periodontitis (Blobel et al. 1987) and in sheep with "broken mouth" (McCourtie et al. 1989, Duncan et al. 2003).

Porhyromonas and Prevotella genera have a wide range of virulence factors, such as collagenase production, a series of proteases, superantigens, endotoxins, fatty acids, hydrogen sulfide, ammonium, $\mathrm{NH}_{3}, \mathrm{H}_{2} \mathrm{~S}$, cytolysins and he- molysins that collaborate to the destruction of periodontal tissues (Haffajee \& Socransky 1994, Deshpande \& Khan 1999, Holt \& Ebersole 2005), that occurs in a significantly elevated pace in ungulate species when compared to pet animals and humans. Thus, although there is awareness of several aspects of pathology, bacteriology and epidemiology that corroborates the infectious etiology, the disease etiopathogenesis and detailed composition of the microbial flora associated with "cara inchada" are aspects further to be elucidated. Aiming to expand the knowledge about the microbial flora involved in bovine periodontitis, the present study focused on identifying species of Porphyromonas and Prevotella genera using polymerase chain reaction (PCR) in samples of bovine subgingival biofilm with or without periodontitis.

\section{MATERIALS AND METHODS}

Clinical characterization of periodontitis and sample collection. The clinical status of 6 to 24-month-old cattle was established after intra-oral and periodontal examination, considering during all stages the Ethics Committee on Animal Experiment criteria (Process FOA no 2013-01402). Periodontal lesions were identified by the same indicators proposed by Döbereiner et al. (1974), which consist of some visible dental aspects. We performed oral examination after animal containment with the aid of a mouth opener and a probe to measure the depth of periodontal pockets.

Samples were obtained from periodontal pocket of injured cattle $(n=26)$ and from gingival sulcus of cattle considered periodontally healthy $(n=25)$. The first were collected from animals raised in farms considered endemic and the second were taken from cattle reared in areas harmless for the disease. The gingival sulcus collection was carried out between the palatal medial portion of the second and the third premolar. In animals with injuries, only pockets with probing depth deeper than $5 \mathrm{~mm}$ were collected. In both groups the samples were collected with sterilized paper point, according to the procedures described by Gaetti-Jardim Jr et al. (2012).

The examined cattle were categorized according to the following characteristics: (1) presence or absence of recession of gums, (2) destruction of supporting tissues characterized by the existence of periodontal pockets (measured by periodontal probe), and (3) the presence or absence of halitosis, as reported by Döbereiner et al. (1974). Twenty-six animals with periodontitis had gingival recession and consequently bone loss (periodontal pockets); therefore, it was used as an indicator of periodontitis in the statistical analysis.

When needed, samples of periodontal pocket were gathered after food removal, and the sampling procedures for collection of gingival sulcus or periodontal pocket material were performed as described by Gaetti-Jardim Jr et al. (2012).

Bacterial identification by polymerase chain reaction (PCR). Each sample for bacterial DNA detection in sterile ultrapure water was priory performed by commercial DNA extraction kit (GenElute Mammalian Genomic DNA Miniprep Kit, Sigma). The presence of Porphyromonas asaccharolytica, P. endodontalis, P. gingivalis, P. gulae, Prevotella buccae, $P$. intermedia, P. loescheii, $P$. melaninogenica, $P$. nigrescens, $P$. oralis and $P$. tannerae was evaluated with the use of specific primers and conditions of DNA amplification (Table 1).

Amplifications were performed in $25 \mu$ l volumes containing $11.9 \mu \mathrm{l}$ water for PCR, $5 \mu \mathrm{l} \mathrm{PCR} / \mathrm{Mg}^{++}$buffer (Boehringer Mannheim, Indianapolis, IN, USA), $1 \mu \mathrm{l}$ dNTP (Pharmacia Biotech, Piscataway, NJ, USA), 0.1 $\mu$ l Taq DNA polymerase (Invitrogen do Brasil, São Paulo, SP, Brazil), $0.2 \mu$ l of each primer pair (Invitrogen do Brasil) 
Table 1. Polymerase chain reaction (PCR) primers used to identify Porphyromonas and Prevotella species within subgingival microflora of cattle with periodontitis and healthy sites of animals without clinical evidence of the disease

\begin{tabular}{|c|c|c|c|}
\hline Porphyromonas/Prevotella species & $\begin{array}{l}\text { Primers } \\
\left(5^{\prime}-3^{\prime}\right)\end{array}$ & $\begin{array}{c}\text { Annealing } \\
\text { temperature }\end{array}$ & Primers references \\
\hline Porphyromonas asaccharolytica & CTC-TAG-CTA-GAG-TGT-ACT-GG ATA-GGG-TTT-ATA-GAT-TAG-CTC-TCT & $60^{\circ} \mathrm{C}$ & Tran et al. 1997 \\
\hline Porphyromonas endodontalis & GCT-GCA-GCT-CAA-CTG-TAG-TC CCG-CTT-CAT-GTC-ACC-ATG-TC & $60^{\circ} \mathrm{C}$ & Fouad et al. 2002 \\
\hline Porphyromonas gingivalis & AGG-CAG-CTT-GCC-ATA-CTG-CG CTG-TTA-GCA-ACT-ACC-GAT-GT & $60^{\circ} \mathrm{C}$ & Ashimoto et al. 1996 \\
\hline Porphyromonas gulae & TTG-CTT-GGT-TGC-ATG-ATC-GGG-CTT-ATT-CT TAC-GGT-ACA-TTC-ACA & $60^{\circ} \mathrm{C}$ & Kato et al. 2011 \\
\hline Prevotella buccae & TCC-TCC-TTT-GAA-GGC-ATC-TGAGTT-GGG-CCG-CTG-CTT-TT & $60^{\circ} \mathrm{C}$ & Nadkarni et al. 2012 \\
\hline Prevotella intermedia & CGT-GGA-CCA-AAG-ATT-CAT-CGG-TCTT-TAC-TCC-CCA-ACA-AAA-GCA & $55^{\circ} \mathrm{C}$ & Ashimoto et al. 1996 \\
\hline Prevotella loescheii & TGC-CAA-CTC-CCG-ATT-TCTAC-ACC-AAG-GTT-TTC-CCC & $58^{\circ} \mathrm{C}$ & Nadkarni et al. 2012 \\
\hline Prevotella melaninogenica & CGT-CAT-GAA-GGA-GAT-TGGATA-GAA-CCG-TCA-ACG-CTC & $59^{\circ} \mathrm{C}$ & Nadkarni et al. 2012 \\
\hline Prevotella nigrescens & ATG-AAA-CAA-AGG-TTT-TCC-GGT-AAGCCC-ACG-TCT-CTG-TGG-GCT-GCG-A & $55^{\circ} \mathrm{C}$ & Ashimoto et al. 1996 \\
\hline Prevotella oralis & TTC-CCA-TTA-CTA-CGG-CAT-ACC-CCCG-CCT-GCT-TAC-TGC-GTA-C & $60^{\circ} \mathrm{C}$ & Nadkarni et al. 2012 \\
\hline Prevotella tannerae & CTT-AGC-TTG-CTA-AGT-ATG-CCGAGC-TGA-CTT-ATA-CTC-CCG & $60^{\circ} \mathrm{C}$ & Mayanagi et al. 2004 \\
\hline
\end{tabular}

and $5 \mu \mathrm{l}$ of the sample. This amplification was performed in a PCR apparatus (Perkin Elmer GeneAmp PCR System 9700, Norwalk, CT, USA) programmed for one cycle at $94^{\circ} \mathrm{C}(5 \mathrm{~min})$, and 30 to 36 cycles at $94^{\circ} \mathrm{C}(1 \mathrm{~min})$. The annealing temperature of each primer was programmed for a time ranging from 30 seconds to 1 minute, $2 \mathrm{~min}$ at $72^{\circ} \mathrm{C}$ and a final extension of $5 \mathrm{~min}$ at $72^{\circ} \mathrm{C}$. PCR amplification products were subjected to electrophoresis on $1 \%$ agarose gel and staining with ethidium bromide $(0.5 \mathrm{mg} / \mathrm{ml})$. As positive controls were used DNA samples of reference strains (Gaetti-Jar$\operatorname{dim}$ Jr et al. 2012).

Statistical analysis. Data were plotted and analyzed using SPSS software. Prevalence and risk analysis was performed using Cochran and Mantel-Haenszel statistics for dichotomous variable or Pearson's Chi-Square test for analysis of proportions when variables had 3 or more categories. Interrelations between clinical and microbiological parameters were assessed by Student's T test and Spearman Correlation Test. Statistical tests were carried out using Bonferroni correction with p-value adjusted from 0.05 to 0.00357 , due to detection of 8 microbial species.

\section{RESULTS}

Among black-pigmented Porphyronomas and Prevotella detected in samples of cattle with periodontitis, $P$. endodontalis $(80.7 \%)$, P. melaninogenica $(73.1 \%)$ and P. intermedia $(61.5 \%)$ were the most predominant. Regarding non-injured cattle $(n=25)$ P. endodontalis $(40 \%)$ and $P$. loeschei (40\%) prevailed. Porphyromonas gingivalis, $P$. gulae and Prevotella tannerae were not detected in the 51 samples studied (Table 2, Fig.1).

Table 2. Porphyromonas and Prevotella species detected by PCR in periodontal pocket $(n=26)$ of cattle with periodontitis and gingival sulcus of healthy animals $(n=25)$

\begin{tabular}{lccc}
\hline \multicolumn{1}{c}{ Species } & $\begin{array}{c}\text { Periodontal } \\
\text { pocket } \mathrm{n}(\%)\end{array}$ & $\begin{array}{c}\text { Gingival } \\
\text { sulcus } \mathrm{n}(\%)\end{array}$ & $P$ \\
\hline Porphyromonas asaccharolytica & $14(53,8)$ & $0(0.0)$ & $0,000003^{*}$ \\
Porphyromonas endodontalis & $21(80,7)$ & $10(40,0)$ & $0,0023^{*}$ \\
Porphyromonas gingivalis & $0(0.0)$ & $0(0.0)$ & \\
Porphyromonas gulae & $0(0.0)$ & $0(0.0)$ & \\
Prevotella buccae & $12(46,1)$ & $2(8,0)$ & $0,0017^{*}$ \\
Prevotella intermedia & $16(61,5)$ & $5(20,0)$ & $0,0020^{*}$ \\
Prevotella loescheii & $14(53,8)$ & $10(40,0)$ & 0,33 \\
Prevotella melaninogenica & $19(73,1)$ & $5(20,0)$ & $0,00006^{*}$ \\
Prevotella nigrescens & $11(42,3)$ & $2(8,0)$ & 0,0042 \\
Prevotella oralis & $13(50,0)$ & $3(12,0)$ & $0,0028^{*}$ \\
Prevotella tannerae & $0(0.0)$ & $0(0.0)$ &
\end{tabular}

* Significant values of $\mathrm{p}$ by Student's T test.

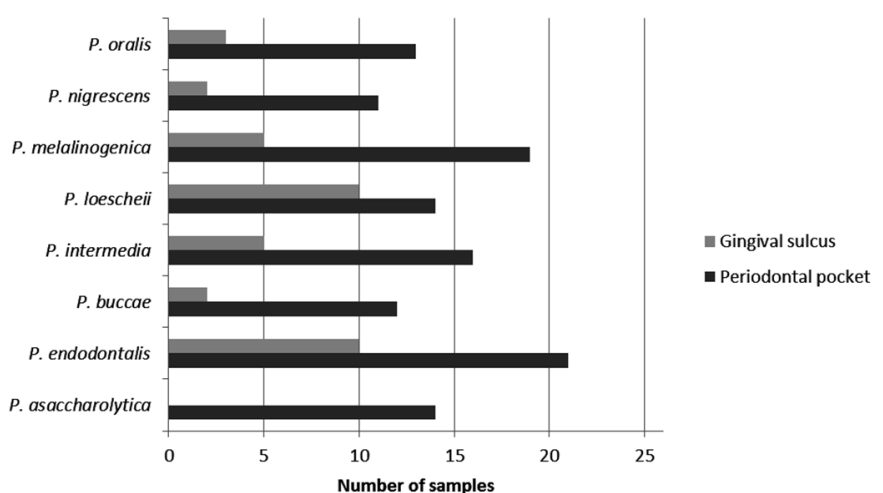

Fig.1. Prevalence of Porphyromonas and Prevotella species identified by PCR in periodontal pocket of cattle with periodontitis and gingival sulcus of periodontally healthy animals.

Table 2 displays that the presence of $P$. asaccharolytica, P. endodontalis, Prevotella buccae, P. intermedia, P. melaninogenica and $P$. oralis is linked to bone loss. Evaluating other characteristics of the animals, it was verified that $P$. asaccharolytica $(p=0.0000001)$, . buccae $(p=0.0000001), P$. melaninogenica $(p=0.0018)$ and P. oralis $(p=0.0038)$ were more prevailing in animals with halitosis.

By Spearman correlation test, a strong positive association between presence of $P$. asaccharolytica and $P$. buccae (Correlation Index - CI varying from 0.663 to 0.76 ) was observed, followed by $P$. intermedia, $P$. melaninogenica, $P$. oralis and P. nigrescens (CI of 0.313 to 0.426 ).

The correlation data suggest the existence of ecological interaction between tested microorganisms, particularity between $P$. asaccharolytica and $P$. buccae (CI=0.507), $P$. endodontalis and $P$. melaninogenica $(\mathrm{CI}=0.435)$, $P$. intermedia and $P$. melaninogenica (IC=0.408), $P$. loescheii and $P$. nigrescens $(\mathrm{CI}=0.440), P$. oralis and $P$. buccae $(\mathrm{IC}=0.436)$, although positive correlation has been observed between other anaerobes studied.

\section{DISCUSSION}

Periodontal breakdown in humans is strongly associated with dysbiosis of the periodontal microbiota, producing relevant changes in the relative abundance of individual components of the dental biofilm and modification in host-microbe relationship sufficient to mediate destructive inflammation and bone loss, which are linked to presence 
of black pigmented anaerobes, $P$. gingivalis in particular (Hajishengallis 2014, Hajishengallis 2015, Amaliya et al. 2015). Other species such as $P$. intermedia, $P$. melaninogenica and $P$. loescheii have been isolated from healthy periodontal sites and their populations and occurrence are significantly higher in patients and periodontal sites presenting conjunctive attachment loss (Darout 2014, Dahlén et al. 2014, Amaliya et al. 2015). Similar results have been described in other host species, as in cats (Pérez-Salcedo et al. 2015) and in dogs (Hardham et al. 2005, Nishiyama et al. 2007, Riggio et al. 2011, Senhorinho et al. 2011).

Bovine periodontitis occurs under specific epidemiological conditions and is predominantly associated with presence of anaerobic bacterial microflora in subgingival biofilm, especially by black-pigmented Bacteroides, Fusobacterium and other microorganisms (Döbereiner et al. 2000, Dutra et al. 2000). Despite of scarce data regarding microbiological aspects of this disease, it was observed through culture method, that the black-pigment species constitute $80 \%$ of subgingival microflora in diseased calves (Botteon et al. 1993, Dutra et al. 2000), although distribution of different species has not been widely evaluated yet.

Dutra et al. (2000) observed that while periodontal pockets in calves with periodontitis contained black-pigment average percentage of $71.3 \%$ of total microflora cultivated in anaerobic conditions and specific culture method, the same animals showed only $1.7 \%$ after the vanishing of inflammation clinical symptomatology, suggesting that these microorganisms can be more prevailing and abundant during the most active disease period, by the time conjunctive attachment loss occurs, as observed in humans.

Different species of Porphyromonas and Prevotella were identified in dogs with periodontitis; among them were Porphyromonas gingivalis, $P$. endodontalis, $P$. gulae, $P$. cangingivalis, $P$. denticanis, P. salivosa, Prevotella intermedia (Hardham et al. 2005, Nishiyama et al. 2007, Riggio et al. 2011, Senhorinho et al. 2011), while Porphyromonas spp., P. gulae and Tannerella forsythia (Booij-Vrieling et al. 2010) were identified in cats with periodontal disease. In other animal species, like non-human primates, the species of the two genera prevailed and in individuals with periodontal inflammation and attachment loss (Holt \& Ebersole 2005). Porphyromonas gingivalis and P. gulae were also isolated from oral cavities of kangaroos suffering from periodontal disease (Mikkelsen et al. 2008). Moreover, various species of Prevotella were isolated from oral cavity of donkeys, such as Prevotella dentasini, $P$. denticola, $P$. intermedia, $P$. loescheii, P. melaninogenica and P. nigrescens (Takada et al. 2010). Additionally, P. gingivalis and P. intermedia were frequently observed in sheep with periodontitis (Duncan et al. 2003), as well as P. asaccharolytica and P. buccae (McCourtie et al. 1989).

Statistical analysis enabled to verify that the occurrence of Porphyromonas asaccharolytica, P. endodontalis, Prevotella buccae, $P$. intermedia, $P$. melaninogenica and $P$. oralis is associated with bone loss and as consequence to bovine periodontitis. Our results reinforce the relationship between these anaerobes and the inflammatory periodontal conditions, but also present few peculiarities not yet described, like absence of $P$. gingivalis in evaluated samples. However, other species of this genus and of the entire pigmented group were very frequent, suggesting, that the ecological niche which this species plays in humans is being occupied by other microorganisms in cattle, such as $P$. asacharolytica and P. endodontalis (Table 2).

The presence of Porphyromonas endodontalis in oral infections is unusually reported by studies based on cultivation, once this microorganism rarely develops in culture mediums (Lillo et al. 2004). Nevertheless, in this study, using PCR techniques, $P$. endodontalis demonstrated a substantial association with periodontitis.

Prevotella intermedia is the second pigmented to receive considerable interest in human periodontitis. The levels of this rod are particularly high in certain types of periodontitis and in progressive sites of the chronic type (Socransky \& Haffajee 2010). P. intermedia is the black-pigmented most frequently isolated from suppurative infections such as periodontal abscesses and apical periodontitis, in addition to extra-oral infection (Mättö et al. 1997, Herrera et al. 2000, Jaramillo et al. 2005). Prevotella intermedia and Prevotella nigrescens are not distinguished by conventional methods of cultivation identification (Ashimoto et al. 1996, Nishiyama et al. 2007). On the other hand, PCR use enabled to evidence that $P$. intermedia is associated with bovine periodontitis, while $P$. nigrescens did not demonstrate significant values.

Porphyromonas asaccharolytica is a black-pigmented prevailing in intestinal and urogenital tract beyond its importance in several non-oral infections. A few studies affirmed that this microorganism is rarely found in human oral microbiota and it is not able to colonize periodontal pockets (Slots 1979, Haffajee \& Socransky 1994, Moore \& Moore 1994, Tran et al. 1997). Distinctly, our study showed a clear association of $P$. asaccharolytica with bovine periodontitis.

Nadkarni et al. (2012) evidenced the correlation of $P$. oralis with periodontal disease and deep periodontal pockets, while $P$. melaninogenica is associated to healthy sites. In this study, both microorganisms showed great associations with bovine periodontitis.

We had selected the genera Porphyromonas and Prevotella as focus of this study because of their notable diversity in species and association with periodontal disease of several species. Nonetheless, such diversity would increase likelihood of non-identified species. In present study, $P$. asaccharolytica, $P$. endondotalis, $P$. buccae, $P$. oralis, $P$. intermedia and $P$. melaninogenica showed strong association with lesions of bovine periodontitis. The identification of the species belonging to Prevotella and Porphyromonas genera in periodontal pockets of cattle is an original and important contribution for studies on pathogenesis and control measures of bovine periodontitis.

\section{CONCLUSIONS}

This investigation suggests the etiologic role of bacteria in bovine periodontitis, probably initiating the inflammatory response and leading to attachment bone loss derived from the action of mediated factors (IL-1, TNF, prostaglan- 
dins, complement, RANKL), as observed in human periodontitis (Hajishengallis 2015, Hajishengallis et al. 2015, Pandit et al. 2015).

The present results also highlight the significance of black pigmented anaerobes in the etiology of periodontal inflammation in cattle.

The presence of periodontal pathogen Porphyromonas and Prevotella species and their association with periodontal lesions corroborate the evidence of the bacterial dysbiosis effect in the infectious multifactorial etiology of bovine periodontitis.

The use of PCR allowed identification of the black pigmented species that do not grow in standard anaerobic culture media.

Acknowledgments.- This study was supported by grants of Fundação de Amparo à Pesquisa do Estado de São Paulo (FAPESP 2013/13701-7).

\section{REFERENCES}

Amaliya A., Laine M.L., Delanghe J.R., Loos B.G., Van Wijk A.J. \& Van der Velden U. 2015. Java project on periodontal diseases: periodontal bone loss in relation to environmental and systemic conditions. J. Clin. Periodontol. 42:325-332.

Ashimoto A., Chen C., Bakker I. \& Slots J. 1996. Polymerase chain reaction detection of 8 putative periodontal pathogens in subgingival plaque of gingivitis and advanced periodontitis lesions. Oral Microbiol. Immun. 11:266-273.

Blobel H., Döbereiner J., Rosa I.V., Lima F.G.F. \& Dutra I.S. 1987. Bacterial investigations of a periodontal disease, Cara Inchada in Brazilian cattle. Tierärztliche Umschau 42:152-154.

Booij-Vrieling H.E., Van Der Reijden W.A., Houwers D.J., De Wit W.E.A.J., Bosch-Tijhof C.J., Penning L.C., Van Winkelhoff A.J. \& Hazewinkel H.A.W. 2010. Comparison of periodontal pathogens between cats and their owners. Vet. Microbiol. 144:147-152.

Botteon R.C.M., Dutra I.S., Döbereiner J. \& Blobel H. 1993. Caracterização de bactérias anaeróbias isoladas de lesões peridentárias da "cara inchada" dos bovinos. Pesq. Vet. Bras. 13(3/4):51-55.

Dahlén G., Claesson R., Aberg C.H., Haubek D., Johansson A. \& Kwamin F. 2014. Subgingival bacteria in Ghanaian adolescents with or without progression of attachments loss. J. Oral Microbiol. 6:1-6.

Darout I.A. 2014. Oral bacterial interactions in periodontal health and disease. J. Dent. Oral Hyg. 6(5):51-57.

Deshpande R.G. \& Khan M.B. 1999. Purification and characterization of hemolysin from Porphyromonas gingivalis A7436. FEMS Microbiol. Lett. 176:387-394.

Döbereiner J., Inada T. \& Tokarnia C.H. 1974. "Cara inchada”, doença peridentária em bovinos. Pesq. Agropec. Bras., Sér. Vet. 9:63-85.

Döbereiner J., Dutra I.S., Rosa I.V. \& Blobel H. 2000. “Cara inchada” of cattle, an infectious, apparently soil antibiotics-dependent periodontitis in Brazil. Pesq. Vet. Bras. 20(2):47-64.

Duncan W.J., Persson G.R., Sims T.J., Braham P., Pack A.R.C. \& Page R.C. 2003. Ovine periodontitis as a potential model for periodontal studies. J. Clin. Periodontol. 30:63-72.

Dutra I.S., Kanoe M. \& Blobel H. 1986. Atividades enzimáticas e endotóxicas de bactérias isoladas de lesões peridentárias da "cara inchada" dos bovinos. Pesq. Vet. Bras. 6:59-63.

Dutra I.S., Matsumoto T. \& Döbereiner J. 1993. Surtos de periodontite em bezerros ("cara inchada") associados ao manejo do solo. Pesq. Vet. Bras. 13(1/2):1-4.

Dutra I.S., Botteon R.C.M. \& Döbereiner J. 2000. Modificação da microbiota associada às lesões peridentárias da "cara inchada" em bezerros transferidos para área indene. Pesq. Vet. Bras. 20(2):71-74.

Fouad A.F., Barry J., Caimano M., Clawson M., Zhu Q., Carver R., Hazlett K.
\& Radolf J.D. 2002. PCR-based identification of bacteria associated with endodontic infectious. J. Clin. Microbiol. 40:3223-3231.

Gaetti-Jardim Jr E., Fardin A.C., Gaetti-Jardim E.C., Castro A.L., Schweitzer C.M. \& Avila-Campos M.J. 2010. Microbiota associated with chronic osteolyelitis of the jaws. Braz. J. Microbiol. 41:1056-1064.

Gaetti-Jardim Jr E., Monti L.M., Ciesielski F.I.N., Gaetti-Jardim E.C., Okamoto A.C., Schweitzer C.M. \& Avila-Campos M.J. 2012. Subgingival microbiota from Cebus apella (capuchin monkey) with different periodontal conditions. Anaerobe 18:263-269.

Haffajee A.D. \& Socransky S.S. 1994. Microbiology and immunology of periodontal diseases. Periodontol. 2000 5:78-111.

Hajishengallis G. 2014. Immunomicrobial pathogenesis of periodontitis: keystones, pathobionts, and host response. Trends Immunol. 35(1):311.

Hajishengallis G. 2015. Periodontitis: from microbial immune subversion to systemic inflammation. Nature 15:30-44.

Hajishengallis G., Lamont R.J. \& Graves D.T. 2015. The enduring importance of animals models in understanding periodontal disease. Virulence 6(3):229-235.

Hardham J., Dreier K., Wong J., Sfintescu C. \& Evans R.T. 2005. Pigmentedanaerobic bacteria associated with canine periodontitis. Vet. Microbiol. 106:119-128.

Herrera D., Roldán S., González I. \& Sanz M. 2000. The periodontal abscess (I). Clinical and microbiological findings. J. Clin. Periodontol. 27:387394.

Holt S.C. \& Ebersole J. 2005. Porphyromonas gingivalis, Treponema denticola, and Tannerella forsythia: the "red complex", a prototype polybacteria pathogenic consortia in periodontitis. Periodontol. 2000 38:72122.

Jaramillo A., Arce R.M., Herrera D., Betancourth M., Botero J.E. \& Contreras A. 2005. Clinical and microbiological characterization of periodontal abscesses. J. Clin. Periodontol. 32:1213-1218.

Kato Y., Shirai M., Murakami M., Mizusawa T., Hagimoto A., Wada K., Nomura R., Nakano K., Ooshima T. \& Asai F. 2011. Molecular detection of human periodontal pathogens in oral swab specimens from dogs in Japan. J. Vet. Dent. 28:84-89.

Lillo A., Booth V., Kyriacou L., Weightman A.J. \& Wade W.G. 2004. Culture-independent identification of periodontitis associated Porphyromonas and Tannerella populations by targeted molecular analysis. J. Clin. Microbiol. 42(12):5523-5527.

Love D.N., Johson J.L. \& Moore L.V. 1989. Bacteroides species from the oral cavity and oral-associated diseases of cats. Vet. Microbiol. 19:275-281.

Love D.N., Vekselstein R. \& Collings S. 1990. The obligate and facultatively anaerobic bacteria of normal flora of the normal feline gingival margin. Vet. Microbiol. 22:267-275.

Mallonee D.H., Harvey C.E., Venner M. \& Hammond B.F. 1988. Bacteriology of periodontal disease in the cat. Arch. Oral Biol. 33:677-683.

Mättö J., Asikainen S. \& Vãisãnem M.L. 1997. Role of Porphyromonas gingivalis, Prevotella intermedia and Prevotella nigrescens in extraoral and some odontogenic infections. Clin. Infect. Dis. 25(2):194-198.

Mayanagi G., Sato T., Shimauchi H. \& Takahashi N. 2004. Detection frequency of periodontitis-associated bacteria by polymerase chain reaction in subgingival and supragingival plaque of periodontitis and healthy subjects. Oral Microbiol. Immun. 19:379-385.

McCourtie J., Poxton I.R., Spence J.A. \& Aitchison G.U. 1989. Preliminary study of the anaerobic bacteria isolated from subgingival plaque from sheep. Vet. Microbiol. 21:139-146.

Mikkelsen D., Milinovich G.J., Burrell P.C., Huynh S.C., Pettett L.M., Blackall L.L., Trott D.J. \& Bird P.S. 2008. Phylogenetic analysis of Porphyromonas species isolated from the oral cavity of Australian marsupials. Environ. Microbiol. 10(9):2425-2432.

Moore W.E.C. \& Moore L.V.H. 1994. The bacteria of periodontal disease. Periodontol. 2000 5:66-77.

Nadkarni M.A., Browe G.V., Chhour K.L., Byun R., Nguyen K.A., Chapple C.C., Jacques N.A. \& Hunter N. 2012. Pattern of distribution of Prevotella spe- 
cies/phylotypes associated with healthy gingiva and periodontal disease. Eur. J. Clin. Microbiol. 31:2989-2999.

Nishiyama S.A.B., Senhorinho G.N.A., Gioso M.A. \& Avila-Campos M.J. 2007. Detection of putative periodontal pathogens in subgingival specimens of dogs. Braz. J. Microbiol. 38:23-28.

Pandit N., Changela R., Bali D., Tikoo P. \& Gugnani S. 2015. Porphyromonas gingivalis: its virulence and vaccine. J Int. Clin. Dent. Res. Organ. 7(1):5158.

Pérez-Salcedo L., Laguna E., Sánchez M.C., Marín M.J., O’Connor A., González I., Sanz M. \& Herrea D. 2015. Molecular identification of black-pigmented bacteria from subgingival samples of cats suffering from periodontal disease. J. Small Anim. Pract. 56:270-275.

Riggio M.P., Lennon A., Taylor D.J. \& Bennet D. 2011. Molecular identification of bacteria associated with canine periodontal disease. Vet. Microbiol. 150:394-400.

Senhorinho G.N.A., Nakano V., Liu C., Song Y., Finegold S. \& Avila-Campos
M.J. 2011. Detection of Porphyromonas gulae from subgingival biofilms of dogs with and without periodontitis. Anaerobe 17:257-258.

Slots J. 1979. Subgingival microflora and periodontal disease. J. Clin. Periodontol. 6:351-382.

Socransky S.S. \& Haffajee A.D. 2010. Infecções periodontais, p.197-254. In: Lindhe J., Lang N.P. \& Karring T. (Eds), Tratado de Periodontia Clínica e Implantologia Oral. 5a ed. Guanabara Koogan, Rio de Janeiro. 1340p.

Socransky S.S., Haffajee A.D., Cugini M.A., Smith C. \& Kent Jr R.L. 1998. Microbial complexes in subgingival plaque. J. Clin. Periodontol. 25(2):134144.

Takada K., Hayashi K., Sato Y. \& Hirasawa M. 2010. Prevotella dentasini sp. nov., a black-pigmented species isolated from the oral cavity of donkeys. Int. J. Syst. Evol. Micr. 60:1637-1639.

Tran T., Flynn M.J., Chen C. \& Slots J. 1997. Absence of Porphyromonas asaccharolytica and Clamydia pneumoniae in human subgingival plaque. Oral Microbiol. Immun. 12(6):377-378. 